\title{
Sodium, potassium, water, and haemoglobin in the packed red cells of severe thalassaemia
}

\author{
C. CHOREMIS ${ }^{1}$, CLEOPATRA ECONOMOU-MAVROU, \\ AND CHRISTINA TSENGHI
}

From the Paediatric Clinic of Athens University

SYNOPSIS Sodium, potassium, water, and the mean corpuscular haemoglobin concentration were determined in the packed erythrocytes of children with severe thalassaemia. The concentration of sodium in the packed red cells was higher than normal in a significant proportion of children with thalassaemia whereas potassium in the packed cells and sodium and potassium in the plasma were normal.

On average, the cell water content was a little higher and the mean corpuscular haemoglobin concentration a little lower than normal.

The cation concentrations in the packed cells of thalassaemia are compared with those in other anaemias. Similarities are pointed out between the sodium concentrations in the packed cells of thalassaemia and those from the foetus and children suffering from malnutrition.

Previous work has shown that the packed erythrocytes in many anaemias contained abnormal amounts of water and cations, chiefly potassium. The concentration of potassium in the packed cells was increased in microcytic anaemias, paralleling an increase in cell water (Maizels, 1936; McCance and Widdowson, 1956). In macrocytic anaemias the small increase in potassium reported by Maizels (1936) and Iyer (1958) was not confirmed by Bertcher and Meyer (1952) and was not always accompanied by a rise in the cell water.

The packed erythrocytes in spherocytic anaemias, congenital (Maizels, 1936; Selwyn and Dacie, 1954) or acquired (Selwyn and Dacie, 1954), have been shown to contain less potassium and less water than do normal cells.

In congenital, non-spherocytic haemolytic anaemia the concentration of potassium and the water content of the packed red cells were high in the cases with marked macrocytosis and reticulocytosis (type I) and normal in the cases with only occasional macrocytes and ovalocytes (type II) (Selwyn and Dacie, 1954). These deviations from normal in type II have been attributed to a high proportion of reticulocytes which are known to contain more

Received for publication 20 March 1961

'Supported by a grant from the Société des Produits Nestlé, S.A., Vevey, Switzerland. potassium and more water than do mature erythrocytes (Granick, 1949; Keitel, Berman, Jones, and MacLachlan, 1955; Ponder, 1948).

In all these anaemias the concentration of sodium in the packed erythrocytes was normal.

The red cell potassium content was slightly low in sickle cell anaemia. During sickling the cells lost potassium and gained sodium without appreciable change in the total cation concentration or the water content (Tosteson, 1955; Tosteson, Carlsen, and Dunham, 1955; Tosteson, Shea, and Darling, 1952).

Experimental post-haemorrhagic anaemia in the dog and the rabbit resulted in a rise of the concentration of potassium and, sometimes, that of magnesium in the packed erythrocytes. A greater rise of these cations was observed in the haemolytic anaemia following the administration of phenylhydrazine and was thought to reflect the high proportion of reticulocytes in both these anaemias (Henriques and Ørskov, 1939).

No abnormality was found in the concentrations of sodium and potassium or the water content of the erythrocytes in the anaemia of myelosclerosis (Maizels, 1936).

In one patient with thalassaemia, Selwyn (1953) found that the loss of potassium from the red cells during incubation at $37^{\circ} \mathrm{C}$. was greater than normal. Except for this information, however, nothing is 
known of the concentrations of sodium or potassium in the erythrocytes of thalassaemia. The present investigation records the results in thalassaemia.

\section{MATERIAL AND METHODS}

Venous blood was collected from children with severe thalassaemia and from normal children who served as controls. The group of controls consisted of children convalescing from diseases with no anaemia and no known effect on the concentrations of sodium or potassium in the plasma or the cells. Children taking drugs such as A.C.T.H. or cortisone were carefully excluded.

The concentration of sodium in the plasma and in the packed red cells was determined in 38 children with severe thalassaemia and 42 normal children. In 18 of the thalassaemic and 17 of the normal children plasma and cell potassium was also determined. Haematocrit readings were recorded and the haemoglobin concentration in whole blood determined in order to calculate the mean corpuscular haemoglobin concentration. The latter was also calculated in a further 18 anaemic and 19 normal children. Cell water was measured in 37 thalassaemic and 37 normal children. For greater accuracy anaemic and normal subjects were always investigated in pairs.

After a period of 10 to 12 hours during which no food was allowed, blood was drawn from the antecubital or jugular vein in the usual way and collected into centrifuge tubes containing lithium oxalate. (Lithium oxalate was preferred to other anticoagulants because almost all others contain sodium or potassium which could interfere with the estimation of these cations. On the other hand, it was thought unwise to use defibrinated blood because of the danger of causing haemolysis, especially in blood specimens from patients with thalassaemia, since erythrocytes are known to be mechanically fragile in this anaemia.) The amount of lithium used was not sufficient to give a reading on the flame photometer after dilution of the same order as that used for the blood samples. The plasma was separated as quickly as possible in order to prevent exchange of sodium and potassium between the plasma and the cells.

Sodium and potassium in the plasma and the cells were estimated according to the methods described by Selwyn and Dacie (1954) except that suitable adjustments were made for direct analysis on an E.E.L. flame photometer, which was calibrated with standard dilutions containing $0.3,0.5,0.7$, and $1.0 \mathrm{mg}$. \% of sodium or potassium and the samples made up to a suitable volume to give readings very near those of one of the above standard solutions.

At the beginning of the present study it had been decided to correct the concentrations of cell sodium and potassium for trapped intercellular plasma according to the results of Chaplin and Mollison (1952). Since, however, these authors constructed their calibration curves from normal blood specimens and, moreover, found that plasma trapping was slightly different in the presence of abnormal erythrocytes, it was later thought wiser to construct our own calibration curves for both normal and thalassaemic children. Trapped plasma was, there- fore, measured according to the method of Chaplin and Mollison in 23 children with severe thalassaemia and 33 normal children, and calibration curves were constructed from 72 measurements of thalassaemic and 92 measurements of normal blood. These results are published in detail elsewhere.

In 15 of the anaemic and 18 of the normal children investigated the trapped plasma was estimated at the same time as the cell sodium. In these cases the samples of packed erythrocytes to be used for cell sodium estimations were obtained after centrifuging whole blood at $1,500 \mathrm{~g}$ (3,000 r.p.m. for $30 \mathrm{~min}$., radius $15 \mathrm{~cm}$.) in Wintrobe haematocrit tubes. This was done in order to produce exactly the same conditions for both cell ? sodium and trapped plasma estimations. The results $\vec{A}$ obtained by this method for cell sodium were almost os identical with those obtained by the method of Selwyn ${ }^{\circ}$ and Dacie (1954). In these cases cell sodium was corrected using each child's own value for trapped plasma. 은 In the remaining patients of the present study, in whom the amount of trapped plasma had not been measured, corrections were made using our calibration curves.

The accuracy of the estimations of sodium and potassium was tested by treating standard solutions of these cations at the same time and in exactly the same way as $\mathbb{\Phi}$ the samples of plasma, whole blood, or packed red cells. Recoveries were 99.8 to $106 \%$ (mean $102.7 \%$ ) for sodium $\mathscr{\odot}$ and 96.8 to $106 \%$ (mean $102.6 \%$ ) for potassium. When standard solutions were added to samples of plasma, whole blood, or packed cells, recoveries were 96 to $109 \%$ (mean $102 \%$ ) for sodium and 98 to $104 \%$ (mean $101 \%$ ) for potassium.

Cell water was measured by drying to constant weight $\stackrel{\circ}{\varnothing}$ at $100^{\circ}$ to $105^{\circ} \mathrm{C}$. weighed samples of packed cells prepared as for cell sodium determinations.

Haemoglobin in whole blood was estimated according to the Sanford, Sheard, and Osterberg oxyhaemoglobin method (Kolmer, Spaulding, and Robinson, 1951) and the proportion of alkali-resistant haemoglobin according to the method of Singer, Chernoff, and Singer (1951). Haematocrit readings were recorded after centrifuging at 3,000 r.p.m. for $30 \mathrm{~min}$. (radius $15 \mathrm{~cm}$.) in Wintrobe tubes.

Whenever possible estimations were made in duplicate.

\section{RESULTS}

The normal concentrations of sodium and potassium in the packed erythrocytes were, on the average, close to those found by Maizels (1936), McCance and $N$ Widdowson (1956) and Selwyn and Dacie (1954) in N normal adults (Table I). Erythrocytes in infants up to 2 years of age have been shown to contain more sodium but no more potassium than that accepted as normal for adults (Overman, Etteldorf, Bass, and $\stackrel{\mathcal{Q}}{+}$ Horn, 1951), although they were of adult composi- 7 tion during the first few hours after birth (McCance $\stackrel{0}{\circ}$ and Widdowson, 1956; Overman et al., 1951). In $\stackrel{\odot}{\Phi}$ the present series of normal children the concentra- $\mathbb{\mathbb { Q }}$ tion of sodium in the packed erythrocytes was about 


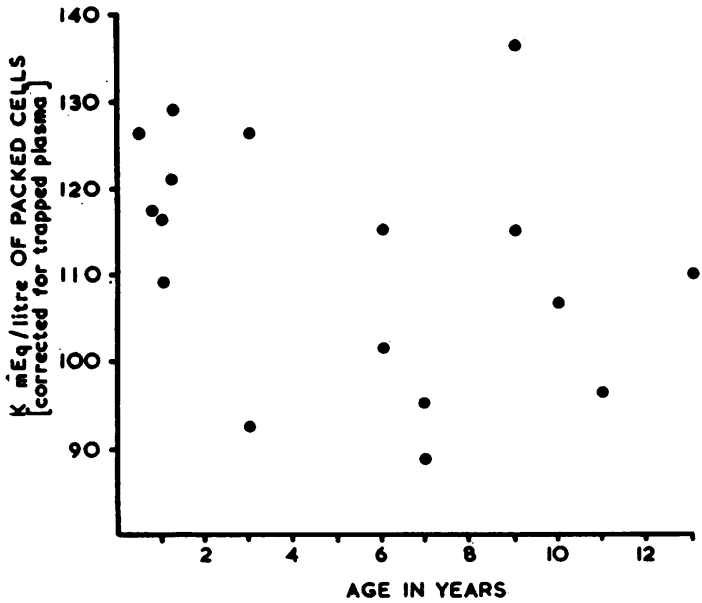

FIG. 1. Relationship between potassium in the packed erythrocytes and age in normal children.

the same in both the babies aged 2 to 24 months and the older children but that of potassium tended to be a little higher in the infant age group (Fig. 1).

Table I shows that the concentration of sodium in the packed red cells was, on the average, higher in the children with thalassaemia. In spite of some degree of overlapping, the mean concentration of sodium was already appreciably higher before the obtained values were corrected for trapped intercellular plasma, but the difference between the anaemic and the normal subjects, expressed as a percentage, was even greater after correction. The difference between the means of the two groups was found to be statistically significant both before and after correction (see Appendix).

As demonstrated in Table II, in 13 out of 38 children with severe thalassaemia (Cases 2, 3, 5, 6, $10,13,24,27,28,29,30,31$, and 32 ) the sodium concentration in the packed red cells exceeded the highest concentration observed in the normal children. In eight of these anaemic children (Cases $3,5,24,28,29,30,31$, and 32) the excess ranged from 25 to $100 \%$. It should be pointed out, however, that when each anaemic child was compared with its own control, there were another seven thalassaemic children in whom the concentration of sodium in the packed cells was higher than normal by 30 to $90 \%$ (Cases $9,14,16,17,23,34$, and 35$)$. This brings the total number of thalassaemic children with high sodium concentrations to $20(52 \%)$. Of the remaining 18 cases, concentrations were about the same as those of their controls in 17 . There was one child (Case 20) in whom the concentration of sodium was considerably less than that of its control.

In nine cases of thalassaemia the cell sodium content was determined twice over a period of a few days to 12 months (Table II). In three of these children (Cases 1, 7, and 14) the concentration was pretty constant. In Case 14 the second estimation was performed a few days after splenectomy but the concentration of sodium remained unchanged in spite of an approximately twofold increase in whole blood haemoglobin and the haematocrit reading. In the remaining children with thalassaemia who were examined twice, the cell sodium varied but it should be pointed out that re-examination generally

\section{TABLE I}

CONCENTRATIONS OF SODIUM AND POTASSIUM AND WATER CONTENTS OF PLASMA AND PACKED ERYTHROCYTES AND AMOUNT OF PLASMA TRAPPED WITHIN THE RED CELL COLUMN IN NORMAL AND THALASSAEMIC CHILDREN

\begin{tabular}{llll} 
Plasma & & \\
\hline $\mathrm{Na}$ & $\mathrm{K}$ & $\mathrm{Na}+\mathrm{K}$ & Water \\
$(\mathrm{mEq.} / l)$. & $(\mathrm{mEq.} / l)$. & $(\mathrm{mEq} / \mathrm{ll})$. & $(\mathrm{g} . / 100 \mathrm{~g})$.
\end{tabular}
Packed Erythrocytes

\begin{tabular}{|c|c|c|c|c|c|}
\hline $\begin{array}{l}\text { Na } \\
\text { (mEq./l. } \\
\text { Uncor- } \\
\text { rected for } \\
\text { Trapped } \\
\text { Plasma) }\end{array}$ & $\begin{array}{l}\text { K } \\
\text { (mEq./l. } \\
\text { Uncor- } \\
\text { rected for } \\
\text { Trapped } \\
\text { Plasma) }\end{array}$ & $\begin{array}{l}\text { Trapped } \\
\text { Plasma } \\
(\% \text { of } \\
\text { Red Cell } \\
\text { Column) }\end{array}$ & $\begin{array}{l}\text { Na } \\
\text { (mEq./l. } \\
\text { Corrected } \\
\text { for } \\
\text { Trapped } \\
\text { Plasma) }\end{array}$ & $\begin{array}{l}\text { K } \\
\text { (mEq./l. } \\
\text { Corrected } \\
\text { for } \\
\text { Trapped } \\
\text { Plasma) }\end{array}$ & $\begin{array}{l}\text { Na+K } \quad \text { Water } \\
(\mathrm{mEq} / \mathrm{l} . \quad(\mathrm{g} . / 100 \mathrm{~g} .) \\
\text { Corrected } \\
\text { for } \\
\text { Trapped } \\
\text { Plasma })\end{array}$ \\
\hline
\end{tabular}

\begin{tabular}{|c|c|c|c|c|}
\hline \multicolumn{5}{|c|}{ Normal children (6 mth. to $13 \mathrm{yr})}$. \\
\hline Maximum & $156 \cdot 4$ & $5 \cdot 82$ & $161 \cdot 2$ & $92 \cdot 5$ \\
\hline Minimum & $121 \cdot 2$ & $4 \cdot 12$ & $138 \cdot 4$ & $90 \cdot 3$ \\
\hline Mean & $135 \cdot 6$ & 5.03 & $146 \cdot 7$ & $91 \cdot 3$ \\
\hline S.D. & $\pm 8 \cdot 9$ & \pm 1.45 & \pm 6.9 & $\pm \mathbf{0 . 5}$ \\
\hline $\begin{array}{l}\text { No. of } \\
\text { observations }\end{array}$ & 42 & 17 & 17 & 28 \\
\hline \multicolumn{5}{|c|}{ Children with severe thalassaemia ( $2 \mathrm{mth}$. to $13 \mathrm{yr}$.) } \\
\hline Maximum & $144 \cdot 6$ & $5 \cdot 87$ & $148 \cdot 1$ & $92 \cdot 6$ \\
\hline Minimum & $124 \cdot 8$ & $4 \cdot 12$ & $135 \cdot 4$ & $90 \cdot 9$ \\
\hline Mean & $134 \cdot 0$ & $4 \cdot 75$ & $141 \cdot 3$ & $91 \cdot 5$ \\
\hline $\begin{array}{l}\text { S.D. } \\
\text { No. of }\end{array}$ & $\pm 5 \cdot 0$ & $\pm 1 \cdot 73$ & $\pm 3 \cdot 6$ & \pm 0.5 \\
\hline & & & 10 & 24 \\
\hline
\end{tabular}

$\begin{array}{rr}19 \cdot 18 & 132.5 \\ 11.40 & 86.4 \\ 15 \cdot 17 & 108.6 \\ \pm 2.17 & \pm 13.6 \\ & \\ 42 & 17 \\ & \\ 34.97 & 130.8 \\ 13.08 & 102.4 \\ 19.86 & 115.0 \\ \pm 5.1 & \pm 8.3\end{array}$

$3 \cdot 55$
$2 \cdot 55$
$3 \cdot 10$
$\pm 0 \cdot 27$

$15 \cdot 95$
$6 \cdot 90$
$11 \cdot 30$
$\pm 2 \cdot 35$

$136 \cdot 8$
$89 \cdot 1$
$112 \cdot 3$
$\pm 13 \cdot 7$

42

42

17

123.0

$55 \cdot 3$

$62 \cdot 7$

$2 \cdot 3$

38

18

$\begin{array}{r}4.95 \\ 2.67 \\ 3 \cdot 82 \\ \pm 0.45 \\ \hline\end{array}$

$32 \cdot 13$
$8 \cdot 43$
$15 \cdot 81$

15.81
+5.4

38

135
103
118
\pm 9
18

17

37

$\begin{array}{rrr}135.9 & 148.9 & 69.6 \\ 103.7 & 120.7 & 58.3 \\ 118.3 & 133.1 & 64.9 \\ \pm 9.1 & \pm 8.4 & \pm 2.1\end{array}$

18

18

37 
TABLE II

CONCENTRATION OF SODIUM IN PACKED ERYTHROCYTES OF NORMAL AND THALASSAEMIC CHILDREN ${ }^{1}$

\begin{tabular}{|c|c|c|c|c|c|c|}
\hline \multicolumn{3}{|c|}{ Normal } & \multicolumn{4}{|c|}{ Thalassaemia } \\
\hline \multirow{5}{*}{$\begin{array}{l}\text { Series } \\
\text { No. } \\
1 \\
2 \\
3 \\
4\end{array}$} & \multirow{2}{*}{$\begin{array}{l}\text { Age } \\
10 \mathrm{yr} .\end{array}$} & \multirow{2}{*}{$\begin{array}{c}\text { Sodium } \\
13 \cdot 34\end{array}$} & \multirow{2}{*}{$\begin{array}{l}\begin{array}{l}\text { Series } \\
\text { No. }\end{array} \\
1 \mathrm{a}\end{array}$} & \multirow{2}{*}{$\frac{A g e}{9 \mathrm{yr} .}$} & \multicolumn{2}{|c|}{ Sodium } \\
\hline & & & & & $10 \cdot 07$ & $10 \cdot 17$ \\
\hline & 9 yr. & 7.90 & $1 b$ & $10 \mathrm{yr}$. & & 9.98 \\
\hline & $7 \mathrm{yr}$. & $7 \cdot 75$ & 2 & 4 yr. & $17 \cdot 52$ & \\
\hline & 3 yr. & 6.90 & $3^{2}$ & 12 mth. & $19 \cdot 86$ & \\
\hline 5 & $12 \mathrm{mth}$. & $11 \cdot 86$ & $4^{2}$ & 3 mth. & $11 \cdot 52$ & \\
\hline 6 & $6 \mathrm{yr}$. & 13.92 & $5 a^{2}$ & $6 \mathrm{mth}$. & 22.49 & $25 \cdot 14$ \\
\hline 7 & $12 \mathrm{yr}$. & $12 \cdot 67$ & $5 b$ & $11 \mathrm{mth}$. & & $19 \cdot 85$ \\
\hline 8 & 14 mth. & 11.49 & 6 & $12 \mathrm{yr}$. & $17 \cdot 23$ & \\
\hline 9 & $11 \mathrm{yr}$. & $11 \cdot 19$ & $7 a$ & $11 \mathrm{mth}$. & $12 \cdot 55$ & $12 \cdot 49$ \\
\hline 10 & 2 yr. & $9 \cdot 70$ & $7 b$ & $14 \mathrm{mth}$. & & 12.60 \\
\hline 11 & 7 yr. & $12 \cdot 43$ & $8^{2}$ & 10 mth. & $12 \cdot 12$ & \\
\hline 12 & $12 \mathrm{mth}$. & $8 \cdot 24$ & 9 & $6 \mathrm{mth}$. & $12 \cdot 25$ & \\
\hline 13 & $13 \mathrm{yr}$. & 8.91 & 10 & $3 \mathrm{yr}$. & $17 \cdot 04$ & \\
\hline 14 & $15 \mathrm{mth}$. & $12 \cdot 57$ & 11 & $2 \mathrm{yr}$. & $14 \cdot 48$ & \\
\hline 15 & $6 \mathrm{mth}$. & $10 \cdot 85$ & 12 & $3 \mathrm{yr}$. & $12 \cdot 61$ & \\
\hline 16 & $9 \mathrm{yr}$. & $11 \cdot 12$ & 13 & $10 \mathrm{mth}$ & $17 \cdot 13$ & \\
\hline 17 & 9 yr. & $9 \cdot 22$ & $\begin{array}{l}14 a \\
14 b^{3}\end{array}$ & $\begin{array}{l}2 \text { yr. } \\
2 \text { yr. }\end{array}$ & 13.97 & $\begin{array}{l}13.94 \\
14.02\end{array}$ \\
\hline 18 & $9 \mathrm{mth}$. & $13 \cdot 07$ & 15 & $2 \mathrm{yr}$. & $13 \cdot 26$ & \\
\hline 19 & $6 \mathrm{yr}$. & $7 \cdot 85$ & 16 & 2 yr. & $15 \cdot 11$ & \\
\hline & & & 17 & $12 \mathrm{mth}$. & $13 \cdot 55$ & \\
\hline 20 & 3 yr. & $12 \cdot 77$ & 18 & 3 yr. & $11 \cdot 56$ & \\
\hline 21 & 10 yr. & 9.96 & 19 & $10 \mathrm{yr}$. & $9 \cdot 38$ & \\
\hline 22 & 2 yr. & $12 \cdot 71$ & 20 & 2 yr. & $8 \cdot 43$ & \\
\hline 23 & 2 yr. & $7 \cdot 66$ & $21 a$ & $14 \mathrm{mth}$. & $12 \cdot 55$ & $9 \cdot 20$ \\
\hline 24 & $3 \mathrm{yr}$. & $13 \cdot 79$ & $21 b$ & 2 yr. & & 15.90 \\
\hline 25 & 2 yr. & 10.06 & 22 & $2 \mathrm{yr}$. & $9 \cdot 14$ & \\
\hline 26 & $10 \mathrm{yr}$. & $10 \cdot 40$ & 23 & $4 \mathrm{yr}$. & 13.49 & \\
\hline 27 & 17 mth. & $9 \cdot 14$ & $24 a$ & $2 \mathrm{yr}$. & $20 \cdot 78$ & $25 \cdot 23$ \\
\hline 28 & 4 yr. & $10 \cdot 76$ & $24 b$ & 3 yr. & & $16 \cdot 34$ \\
\hline 29 & 3 yr. & 13.42 & 25 & 3 yr. & $14 \cdot 38$ & \\
\hline 30 & 12 mth. & 15.95 & 26 & $14 \mathrm{mth}$. & $14 \cdot 88$ & \\
\hline 31 & 12 mth. & $10 \cdot 55$ & $27^{2}$ & $11 \mathrm{yr}$. & 17.97 & \\
\hline 32 & 12 yr. & $15 \cdot 23$ & $28 a$ & $13 \mathrm{yr}$. & 22.91 & $26 \cdot 23$ \\
\hline 33 & $12 \mathrm{yr}$. & 13.92 & $\begin{array}{l}28 b \\
29 a\end{array}$ & $\begin{array}{l}13 \mathrm{yr} . \\
19 \mathrm{mth} .\end{array}$ & & $\begin{array}{l}19 \cdot 59 \\
26.98\end{array}$ \\
\hline 34 & $7 \mathrm{yr}$. & $9 \cdot 70$ & $29 b$ & $19 \mathrm{mth}$. & $32 \cdot 13$ & $42 \cdot 32$ \\
\hline 35 & 9 mth. & 13.06 & $29 c$ & 19 mth. & & $27 \cdot 10$ \\
\hline & & & 30 & 5 yr. & $28 \cdot 24$ & \\
\hline 36 & $8 \mathrm{mth}$. & 14.85 & 31 & $14 \mathrm{mth}$. & 29.87 & \\
\hline & & & $32 a$ & $7 \mathrm{mth}$. & $21 \cdot 05$ & $23 \cdot 38$ \\
\hline 37 & $7 \mathrm{mth}$. & $9 \cdot 90$ & $32 b$ & $7 \mathrm{mth}$. & & $18 \cdot 72$ \\
\hline 38 & $4 \mathrm{mth}$. & $15 \cdot 23$ & 33 & $2 \mathrm{mth}$. & 14.04 & \\
\hline 39 & $5 \mathrm{yr}$. & $8 \cdot 54$ & 34 & $6 \mathrm{yr}$. & $14 \cdot 68$ & \\
\hline 40 & $4 \mathrm{yr}$. & $10 \cdot 82$ & 35 & $4 \mathrm{yr}$ & $14 \cdot 08$ & \\
\hline 28 & $4 \mathrm{yr}$. & 10.99 & 36 & $3 \mathrm{yr}$. & $12 \cdot 88$ & \\
\hline 41 & 4 yr. & $11 \cdot 70$ & 37 & $6 \mathrm{yr}$. & $13 \cdot 23$ & \\
\hline 42 & $13 \mathrm{mth}$. & $13 \cdot 63$ & 38 & $11 \mathrm{mth}$. & $14 \cdot 84$ & \\
\hline
\end{tabular}

${ }^{1}$ Results are expressed in mEq./l. corrected for trapped plasma. ${ }^{2}$ Recent blood transfusions

${ }^{3}$ After splenectomy

confirmed the high or normal values which had been obtained initially.

The present series of severe thalassaemia included two pairs of siblings (Cases 16 and 17 and Cases 25 and 26, Table II). The concentrations of cell sodium were almost identical and their haematological data showed little if any variance.

The mean concentration of potassium in the packed erythrocytes of the children with severe thalassaemia was about the same as that of the normal children and so were the concentrations of sodium and potassium in the plasma (Table I, see Appendix). In some of the normal and some of the anaemic subjects the concentration of potassium in the packed erythrocytes was high.

The mean corpuscular concentration of haemoglobin in the normal children (Table III) was, on the $\mathbb{\mathbb { D }}$ average, very close to that reported by other investigators (Wintrobe, 1956) but nine children had ${ }^{\text {कs }}$ values of $38 \%$ or over. This finding, together with $\vec{O}$ the high concentration of cell total base observed in some of the cases, will be discussed later.

\section{TABLE III}

HAEMATOLOGICAL DATA FROM NORMAL CHILDREN AND CHILDREN WITH SEVERE THALASSAEMIA

\begin{tabular}{|c|c|c|c|}
\hline $\begin{array}{l}\text { Haemo- } \\
\text { globin } \\
(\mathrm{g} . / 100 \mathrm{ml} .)\end{array}$ & $\begin{array}{l}\text { Alkali- } \\
\text { resistant } \\
\text { Haemo- } \\
\text { globin }(\%)\end{array}$ & $\begin{array}{l}\text { Volume } \\
\text { Packed } \\
\text { R.B.C.s } \\
(\mathrm{ml} . / 100 \mathrm{ml} .)\end{array}$ & $\begin{array}{l}\text { M.C.H.C. } \\
(\%)\end{array}$ \\
\hline
\end{tabular}

Normal children 6 mth. to $13 \mathrm{yr}$.

Maximum $15.56 \quad 43.5 \quad 41$.

$\begin{array}{llll}\text { Minimum } & 9.43 & - & 30.5\end{array}$

$\begin{array}{llll}\text { Mean } & 12.73 & - & 35.9\end{array}$

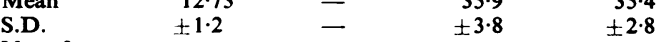

No. of

$55 \quad 61$

$\pm 2 \cdot 8$

observations 55

55

Children with severe thalassaemia $2 \mathrm{mth}$. to $13 \mathrm{yr}$.

$\begin{array}{llll}\text { Maximum } & 13 \cdot 14^{1} & 90 & 33 \cdot 5^{2}\end{array}$

Minimum $\quad 2 \cdot 10$

$\begin{array}{ll}\text { Mean } & 6 \cdot 12\end{array}$

S.D.

No. of

$6 \cdot 12$
$+2 \cdot 07$

24
55

$9 \cdot 0$
$18 \cdot 1$

$18 \cdot 1$

$\pm 4.9$

56

56

${ }^{1}$ Recent blood transfusions

${ }^{2}$ After splenectomy

In the children with severe thalassaemia the mean corpuscular haemoglobin concentration was, on the average, only very slightly lower than normal용 (Table III). In most of them it was normal or slightly :reduced, the reduction being considerable in only five cases. On the contrary, anaemic red cells some- $\delta$ times contained a concentration of haemoglobin which exceeded the highest value obtained from the $ᄋ$ normal children.

That the mean corpuscular haemoglobin concen- $\frac{D}{0}$ tration was, on the average, only slightly reduced in the children with thalassaemia is confirmed by the $\mathrm{N}$ fact that there was an equally slight increase in the $N$ mean cell water of these children. This was $62.7 \%$ N $\mathrm{w} / \mathrm{w}$ in the normal children and $64.9 \% \mathrm{w} / \mathrm{w}$ in thalassaemia. If the specific gravity of the solids is 1.3 (a) likely figure), their volume must have been $28.7 \mathrm{ml}$. and $27.0 \mathrm{ml}$. and cell water $62.7 \times \frac{100}{62 \cdot 7+28.7}=$ $68.6 \% \mathrm{w} / \mathrm{v}$ and $64.9 \times \frac{100}{64.9+27.0}=70.6 \% \mathrm{w} / \mathrm{v}$ respectively. The figures for both the normal and the 
anaemic children are probably a little low (Maizels, 1936; McCance and Widdowson, 1956; Selwyn and Dacie, 1954) but it is obvious that the difference between the two groups is small.

Table IV gives the concentrations of sodium, potassium, and total base per litre of cell water. It is clear that correction for cell water did not alter our findings about the cation concentrations of the packed erythrocytes in severe thalassaemia.

\section{TABLE IV}

CONCENTRATIONS OF SODIUM AND POTASSIUM IN PACKED ERYTHROCYTES OF NORMAL AND THALASSAEMIC CHILDREN

\begin{tabular}{lllll} 
& & $\begin{array}{l}N a \\
(m E q . / l \text { of cell water corrected for } \\
\text { trapped plasma })^{1}\end{array}$ & \\
\hline Normal & Maximum & 23.2 & 199.0 & 215.0 \\
& Minimum & 10.0 & 129.0 & 141.0 \\
& Mean & 16.4 & 163.0 & 180.0 \\
Thalassaemia & Maximum & 46.92 & 189.5 & 210.0 \\
& Minimum & 11.94 & 150.5 & 172.9 \\
& Mean & 22.39 & 167.5 & 189.9
\end{tabular}

${ }^{1}$ Corrections for cell water were made using the calculated values of $68.6 \% \mathrm{w} / \mathrm{v}$ for normal and $70.6 \% \mathrm{w} / \mathrm{v}$ for children with thalassaemia

\section{DISCUSSION}

CONCENTRATIONS OF SODIUM AND POTASSIUM IN THE RED CELLS The results obtained from 38 children with severe thalassaemia show that the concentration of sodium in the packed erythrocytes was, on the average, higher than normal and it is of special

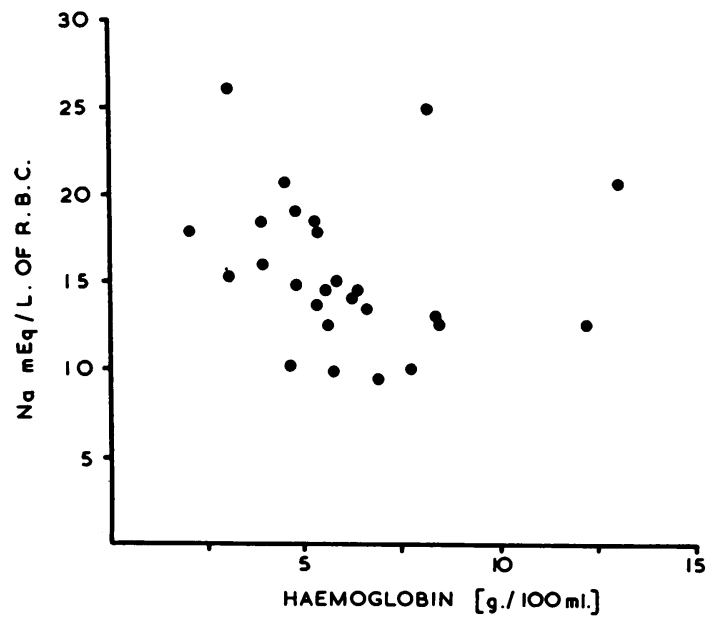

FIG. 2. Relationship between sodium in the packed erythrocytes and haemoglobin in the whole blood in children with severe thalassaemia. (The figures for sodium have been corrected for trapped plasma.) interest that similar studies of the erythrocytes in other anaemias have yielded normal sodium concentrations (Bertcher and Meyer, 1952; Henriques and Ørskov, 1939; Maizels, 1936; McCance and Widdowson, 1956; Selwyn and Dacie, 1954, Tosteson et al., 1952).

The erythrocytes analyzed consisted of a mixture of packed cells and trapped intercellular plasma. Since so much more sodium is contained in the plasma than in the packed cells, it was necessary to correct the sodium values obtained for trapped plasma, for it could be suggested that the higher concentration of sodium in thalassaemia had resulted from a greater amount of plasma trapped between the centrifuged red cells of this anaemia. The investigation of 23 of the children with severe thalassaemia in the present series revealed a somewhat greater amount of plasma remaining with the erythrocytes after centrifugation (Table $\mathrm{I}$ ), but this was not sufficient to account for the increased concentration of sodium which was found in their packed cells. The sodium concentrations, therefore, remained higher than normal even after correction for trapped plasma.

Because of the wide spread in the concentrations of sodium in the packed cells of the children with thalassaemia, the question was raised whether cell sodium was related to the severity of the anaemia. Although higher concentrations tended to be found in patients who appeared to be severely ill, there was no correlation between the sodium concentration and the degree of the anaemia (Figs. 2 and 3).

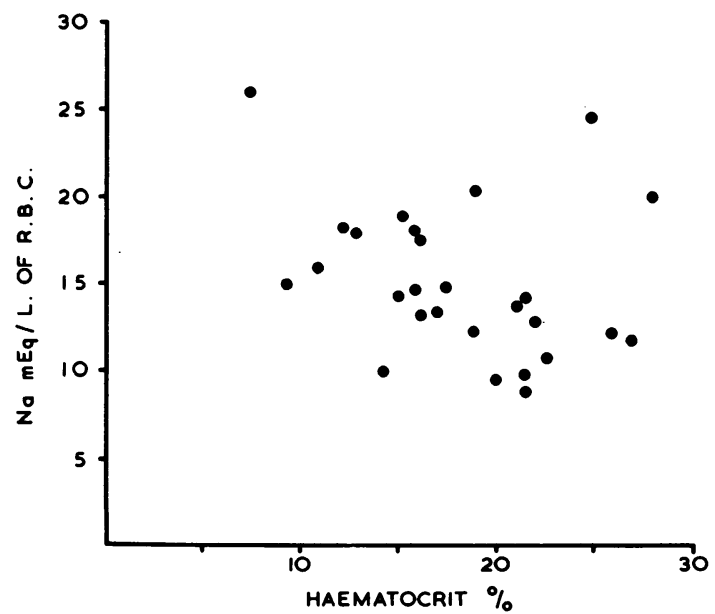

FIG. 3. Relationship between sodium in the packed erythrocytes and the packed cell volume in children with severe thalassaemia. (The figures for sodium have been corrected for trapped plasma.) 
Cases 3, 4, 5a, 8, and 27 (Table II) had a relatively high haematocrit reading and haemoglobin concentration, the result of recent blood transfusions. These children were severely anaemic and had, therefore, been transfused with large quantities of blood before they were examined. The presence of normal erythrocytes would have been expected to lower the sodium concentrations in the packed cells. Yet, the latter were appreciably high in Cases $3,5 \mathrm{a}$, and 27 . This observation, together with the fact that only very few cases have been examined under such conditions, makes the effect of blood transfusions on the concentration of sodium in the packed red cells very difficult to interpret.

An important question was whether the high sodium concentrations in the packed cells of many children with severe thalassaemia reflected an increase in the sodium content of the individual erythrocyte. Conclusions about the contents of individual erythrocytes can only be reached if their mean volume is known. Thus, with small erythrocytes each unit volume of packed cells includes a large number of cells; hence, if the sodium content of a small cell be the same as that of a normal cell, then a unit volume of small packed cells will be found to contain more sodium than the same unit of normal packed cells and the opposite is true of large cells. The mean cell volume was not calculated in the present study because of the large error involved in the enumeration of erythrocytes, but thalassaemia is known to belong to the microcytic anaemias. Nevertheless, it is very unlikely that the high concentration of sodium in the packed cells of many children with thalassaemia had resulted from a small mean cell volume, since the packed cells of microcytic anaemias other than thalassaemia have been shown to contain normal concentrations of sodium (Maizels, 1936; McCance and Widdowson, 1956). Furthermore, if microcytosis were responsible for the high concentrations of sodium, it would be very difficult to explain why it did not cause a proportional rise in the concentration of potassium in the packed cells of thalassaemia. It therefore appears that the average red cell in the thalassaemic children with high sodium concentrations in the packed cells did contain more sodium than normal. Unfortunately, information about the intracellular composition of the individual erythrocyte may be provided from the calculation of the mean cell volume only when all the cells are of similar size. In view of the marked variation in the size and shape of the erythrocytes in thalassaemia, one should be able to sort them into their various sizes and examine each size separately in order to estimate its intracellular composition. When this can be done, it may be possible to determine whether it is all the red cells in this anaemia or only a certain cell population which contains an increased amount of sodium. $\stackrel{\vec{P}}{+}$ Until then, one must perforce express results and? compare them with those obtained from other $\frac{\overline{\bar{D}}}{\bar{\rho}}$ erythrocytes in terms of concentration per unit $\frac{\bar{\Phi}}{\bar{\phi}}$ volume of packed cells.

In these terms the mean cell sodium in thalassaemia was higher than that of normal children, $\vec{\circ}$ higher than that of other anaemias, but comparable with that of the foetus and the severely malnourished $\vec{\omega}$ pig (McCance and Widdowson, 1956). This similarity? between thalassaemic red cells on the one hand and? those from the foetus and malnourished pigs on the $\vec{A}$ other is interesting, because both thalassaemic and 9 foetal erythrocytes contain a large proportion of ${ }^{\circ}$ alkali-resistant (foetal ?) haemoglobin and mal-

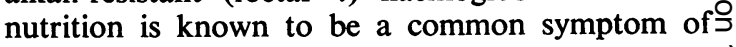
severe thalassaemia.

The potassium concentration in the packedo erythrocytes was approximately the same in bothळ the normal and the thalassaemic children. This again $\overline{0}$ differentiates thalassaemia from other types of $\stackrel{\Phi}{ }$ anaemia in which it was the potassium not the $\vec{\bullet}$ sodium concentration which was abnormal (Hen-oึ riques and Ørskov, 1939; Maizels, 1936; McCance and Widdowson, 1956; Selwyn and Dacie, 1954; Tosteson et al., 1952).

As already mentioned, in some of the normal and some of the anaemic children of the present study the $\frac{\mathrm{O}}{\mathrm{O}}$ concentration of total base in the packed erthrocytes was high. Several figures for the mean corpuscularô을 haemoglobin concentration were also high, whereas the average cell water in normal children was a? little lower than that reported by other workers: (Maizels, 1936; McCance and Widdowson, 1956; Selwyn and Dacie, 1954). These findings may all be:tied up with the use of lithium oxalate as an anti- 3 . coagulant which must have caused cells to shrink by raising the osmotic equivalence of the plasma. The degree of cell dehydration would vary if theo lithium oxalate did not always dissolve completely and this would explain why some but not all of theo figures for total base or the mean corpuscular haemoglobin concentration were high. Nevertheless, it is very unlikely that lithium oxalate caused an greater dehydration in thalassaemic red cells than in N normal cells. A greater cell shrinkage in thalassaemiao would certainly explain the higher concentration of sodium found in the packed cells, but, were the increase in sodium the result of cell dehydration, $?$ the latter should have caused a proportional rise in the concentration of potassium.

MEAN CORPUSCULAR CONCENTRATION OF HAEMO-西 GLOBIN The normal or only slightly reduced mean corpuscular concentrations of haemoglobin found 
in the present group of thalassaemia are not in general agreement with those previously observed by other investigators. In thalassaemia the mean corpuscular haemoglobin concentration is usually low (Lie-Injo Luan Eng, Kho Lien Keng, Liem Djwan Lioe, and Oei Oen Bie, 1959; Marmont and Bianchi, 1947; Minnich, Supa Na-Nakorn, Soodsarkon Chongchareonsuk, and Su-Ed Kochaseni, 1954; Sturgeon and Finch, 1957; Wintrobe, 1956) but it has already been demonstrated that it may be relatively normal (Lehmann, 1959; Lie-Injo Luan Eng et al., 1959; Mathoth, Shamir, and Freundlich, 1955). This controversy may be due to differences in the morphology of the erythrocytes in the subjects studied by each group of investigators and similar differences may partly explain the wide spread in the values obtained from the present series.

More puzzling is the fact that the mean corpuscular haemoglobin concentration was higher than normal in a number of our cases. With the exception of spherocytes and ovalocytes, which have occasionally been shown to contain concentrations of haemoglobin which were slightly raised (Maizels, 1936; Selwyn and Dacie, 1954; Wintrobe, 1956), red cells with abnormal concentrations of haemoglobin are 'hypochromic' not 'hyperchromic'. The reason for this occasional hyperchromia of thalassaemic erthrocytes is obscure. In spherocytes the higher haemoglobin concentration was accompanied by a lower cell water content and it is conceivable that this may be true of some cases with severe thalassaemia.

\section{REFERENCES}

Bertcher, R. W., and Meyer, L. M. (1952). Proc. Soc. exp. Biol. (N.Y.), $81,383$.

Chaplin, H. Jr., and Mollison, P. L. (1952). Blood, 7, 1227.

Fisher, R. A., and Yates, F. (1938). Statistical Tables for Biological, Agricultural and Medical Research. Oliver and Boyd, Edinburgh and London.

Granick, S. (1949). Blood, 4, 404.

Henriques, V., and Ørskov, S. L. (1939). Skand. Arch. Physiol., 82, 86.

Iyer, G. Y. N. (1958). Arch. Biochem. Biophys., 74, 24.

Keitel, H. G., Berman, H., Jones, H., and MacLachlan, E. (1955). Blood, 10, 370.

Kolmer, J. A., Spaulding, E. H., and Robinson, H. W. (1951). Approved Laboratory Technic., 5th ed. Appleton-CenturyCrofts, New York.

Lehmann, H. (1959). Brit. med. Bull., 15, 40.

Lie-Injo Luan Eng, Kho Lien Keng, Liem Djwan Lioe, and Oei Oen Bie (1959). Acta haemat. (Basel), 21, 102.

Maizels, M. (1936). Biochem. J., 30, 821.

Marmont, A., and Bianchi, V. (1947). Pathologica, 39, 9.

Mathoth, Y., Shamir, Z., and Freundlich, E. (1955). Blood, 10, 176.

McCance, R. A., and Widdowson, E. M. (1956). Clin. Sci., 15, 409.

Minnich, V., Supa Na-Nakorn, Soodsarkon Chongchareonsuk, and Su-Ed Kochaseni (1954). Blood, 9, 1.

Overman, R. R. Etteldorf, J. N., Bass, A. C. and Horn, G. B. (1951). Pediatrics, 7, 565.

Ponder, E. (1948). Hemolysis and Related Phenomena. Grune and Stratton, New York.
Selwyn, J. G. (1953). Unpublished observations. Cited by Dacie, J. V. (1954). The Haemolytic Anaemias, Ch. 5. Churchill, London. $\longrightarrow$, and Dacie, J. V. (1954). Blood, 9, 414.

Singer, K., Chernoff, A. I., and Singer, L. (1951). Ibid, 6, 413.

Sturgeon, P., and Finch, C. A. (1957). Ibid, 12, 64.

Tosteson, D. C. (1955). J. gen. Physiol., 39, 55.

, Carlsen, E., and Dunham, E. T. (1955). Ibid, 39, 31.

, Shea, E., and Darling, R. C. (1952). J. clin. Invest., 31, 406.

Wintrobe, M. M. (1956). Clinical Hematology, 4th ed. Lea and Febiger, Philadelphia.

\section{A P P E N D I X}

Statistical treatment of the results of the present investigation (C. Callerghis, statistician, Oxford University) yielded the following results:

CONCENTRATION OF SODIUM IN PACKED RED CELLS The difference between the means of the thalassaemic and the normal children was highly significant. For values uncorrected for trapped intercellular plasma the Behrens test $^{1}$ gave $d=5 \cdot 25, \theta=32^{\circ}$, with $n_{1}-1=37$ and $n_{2}-1=41$ degrees of freedom. The corresponding Sukhatmé table value is not greater than 3.0 at the 0.01 level of significance. For values corrected for trapped plasma $d=4 \cdot 72, \theta=32^{\circ}$ with $n_{1}-1=37, n_{2}-1=41$ degrees of freedom. The Sukhatmé table value is about 3.0 at the 0.01 level of significance.

CONCENTRATION OF POTASSIUM IN PACKED RED CELLS The difference between the means of the two groups examined was not significant. Before correction for trapped plasma $t=1.68$, after correction $t=1.53<2.030(P=0.05)$.

CONCENTRATION OF SODIUM AND POTASSIUM IN PLASMA For sodium $t=0.79$ and for potassium $t=2.109>2.04$ at the $\mathbf{0 . 0 5}$ level of significance.

MEAN CORPUSCULAR HAEMOGLOBIN CONCENTRATION The small difference between the means of the two groups examined was statistically significant. The Behrens test gave $\mathrm{d}=2 \cdot 23, \theta=31^{\circ}$ with $\mathrm{n}_{1}-1=55, \mathrm{n}_{2}-1=54$. The corresponding Sukhatmé table value is not greater than 1.96 at the 0.05 level of significance.

CELl WATER The difference between the means of the two groups examined although small was highly significant for $t=4.294>2.648$ at the 0.01 level of significance.

RELATIONSHIP BETWEEN MEAN CORPUSCULAR HAEMOGLOBIN CONCENTRATION AND CELL WATER An inverse correlation was found between these two variables. In the group of thalassaemic children $r=-0.325$ the Fisher and Yates (1938) table value for $n-2=35$ degrees of freedom at the 0.05 level of significance.

In the group of normal children $r=-0.603>-0.325$, the Fisher and Yates table value for $n-2=35$ degrees of freedom at the 0.05 level of significance.

'The Behrens test has been applied throughout the present study whenever the variances of the concerned groups were shown to differ significantly (F test). 